\title{
Influence of music therapy on the telomere length: a brief review and a pilot study
}

\author{
Irina M. Spivak ${ }^{1,2,3^{*}}$, \\ Tatiana Yu. Smirnova ${ }^{1}$, \\ Arina S. Urazova ${ }^{6}$, \\ Andrey L. Runov',
}

Anastasia A. Vasilishina ${ }^{1}$,

Andrey V. Kropotov',

\section{Dimitri L. Spivak ${ }^{4,5}$}

${ }^{1}$ Institute of Cytology,

Russian Academy of Sciences,

4 Tikhoretskii Ave.,

St. Petersburg 194064, Russia

${ }^{2}$ St. Petersburg State University,

7/9 Universitetskaya Embankment,

St. Petersburg 199034, Russia

${ }^{3}$ St. Petersburg State

Polytechnical University,

Polytekhnicheskaya St., 29,

St. Petersburg 195251, Russia

${ }^{4}$ Human Brain Institute,

Russian Academy of Sciences,

9 Akademika Pavlova St.,

St. Petersburg 197022, Russia

\section{${ }^{5}$ D. S. Likhachev Russian}

Scientific Research Institute of Cultural and Natural Heritage,

20 Bersenevskaya Embankment,

Moscow, 119072, Russia

${ }^{6}$ Universitätsklinikum Halle (Saale),

Ernst-Grube-Str. 40,

Halle (Saale) 06097, Germany
Relation between music perception and telomere length is discussed. Telomeres are now considered as markers of general health and as possible predictor of life expectancy, while their length correlates with either the risk of age-related pathologies or with higher adaptive performance. The ability to withstand agerelated telomere shortening by means of practicing psychological training is discussed. Problems and prospects of present-day music therapy are reviewed, as well as absence of studies of alteration of telomere length, related to music perception. Sixty-three practically healthy young (aged $24 \pm 5$ years) randomly selected Russian-speaking students were divided into three subgroups, each of which listened to music of a specific type for 14 days, 90 minutes each day. Before and after the two-week course, the telomere length and telomerase activity in blood samples were measured. A limited but statistically reliable increase in the telomere length and in telomerase activity is demonstrated to have occurred as a result of completing the music course. Classical music tends to bring about less stress, positively affect one's mood, and physiology, and, finally, such essential aging markers as telomerase activity and the telomere length. Non-classical music conditioned manifestation of some stress, which tended to affect the telomere length in a negative way. In order to cope with this difficulty, telomerase was activated.

Keywords: telomere length, telomerase activity, music therapy

*Corresponding author. Email: irina_spivak@hotmail.com 


\section{INTRODUCTION}

Nowadays music therapy forms an integral part of psychotherapy and/or psychological training, tending to become a discipline on its own. In the early 1990s, a special concept, namely, the Mozart effect, was introduced, mostly due to works which Frances Rauscher and her colleagues started publishing from 1993. Having listened to Mozart's music (Sonata for two pianos, K448) for ten minutes, subjects demonstrated a significant improvement in spatial thinking skills. Results of IQ tests in these subjects increased by $8-9$ points. However, the effect of this kind was mostly short-term. A similar effect was not observed either in the case of relaxation therapy aimed at lowering blood pressure or in the case of a 10-minute silence session (Rauscher et al., 1993).

These results proved to be highly controversial and not sufficiently reproducible (Chabris, 1999). Although some authors succeeded on principle in reiterating them (Rideout, Laubach, 1996; Rideout et al., 1998), Rauscher herself agreed that the Mozart effect was limited in time and did not necessarily lead to a general increase in intellectual abilities (Rauscher, 1999). The main reason for criticism was that one tended to simply enjoy good music, especially if they listen to one of their favourite works. This meant that the Mozart effect could be associated with popularity of a certain kind of music and, consequently, with aesthetic factors. To test this hypothesis, it would be expedient to conduct similar experiments on animals.

Four groups of rats were exposed to music, both in utero and within 60 days after birth. After that, their ability to pass labyrinths was tested. Not only Mozart's piano sonata K448 was applied in this test, but also minimalist music composed by the famous contemporary composer Philip Glass, also white noise and silence. Animals from the first group, i.e., those that had listened to Mozart, succeeded in passing a labyrinth significantly faster and made fewer mistakes in choosing the right path $(P<0.01)$ than those from the other three groups. Thus it was shown that the effect could be linked, at least to some extent, to the inner organization of music and not to its conscious or subconscious human perception (Rauscher et al., 1998).

A large number of studies have been undertaken since then to determine brain zones associated with this kind of perception. First of all, positron emission tomography (PET), and magnetic resonance scanning were used. Perception of music by patients with local brain damage was also investigated. As a result, it was shown that although the main auditory region included transverse and upper temporal gyrus, numerous parts of the brain took part in the process of music perception (and its specific components, like primarily rhythm, melody, and timbre). These numerous parts ranged from the prefrontal cortex, and the upper temporal gyrus to the parietal lobe of the cortex. Perception of rhythm occurred mainly in the left hemisphere, perception of timbre and melody in the right one (Warren, 1999; Platel et al., 1997; Ligeois-Chauvel et al., 1998). Brain areas being responsible for visualization of spatial problems tended to overlap with these regions; they also included prefrontal, temporal, and parietal cortical areas, which was demonstrated especially by means of PET studies (Mellet et al., 1996). Probably it was just the overlapping of the activity of these areas that was responsible for the spatial imagination and perception of music that triggered, when listening to Mozart, their joint activation leading to a temporary improvement in IQ performance in humans.

Initially, all the experiments aimed at studying the impact of Mozart's music were conducted on adult volunteers, and the impact was quite shortterm. At the next stage, groups of children aged 3-4 years were studied: they had regular music lessons for six months, which included not only listening to music, but also learning to perform it (Rauscher et al., 1997). At the end of the course, all children could perform simple melodies by Beethoven and Mozart. Then the children were tested by means of psychological tests adapted to their age, revealing significantly (by 30\%) higher results than the children of the same age who had either special computer lessons or no special training at all. The improvement was limited to 
spatial-temporal reasoning; there was no effect on spatial recognition. The effect persisted for at least 24 hours after the end of the music lessons, however, exact time of improvement was not registered. Compared to previous reports, a longer duration of the effect was due to longer exposure to the music and to greater plasticity of the young brain.

In subsequent experiments, it was shown that those children who were learning to play the piano and had a positive effect of this kind attained higher results in studying mathematics afterwards (Graziano et al., 1999). Following these studies, music lessons in early childhood began to be considered as an important component of preschool education.

In addition to the Mozart effect, a number of studies centered upon direct therapeutic effect of classical music were conducted. The aforementioned effect concerned, for instance, therapy of cardiovascular pathology. It was shown that listening to music can not only improve the quality of life, but also give impetus to positive changes in heart rate (for a summary of results, cf. Trappe, 2010).

A whole block of studies was devoted to the effect of music on patients with convulsive activity and epilepsy. When listening to Mozart's piano sonata, patients revealed presence of epileptomorphic activity, two to ten times, according to EEG indications (Hughes et al., 1998). A positive effect was observed even in comatose patients, which corroborated the hypothesis that conscious evaluation of music was not absolutely necessary to produce the Mozart effect. However the positive effect of the music was short-term, similar to the earlier experiments.

To test the possibility of a longer-lasting effect, an 8-year-old patient with a severe form of childhood epilepsy (Lennox-Gastaut syndrome) was exposed to Mozart's music, for 10 minutes every hour in the course of his wakefulness. This led to a sharp (nine-fold, as a matter of fact) decrease in the clinical and recorded EEG types of convulsive activity, which remained practically at the same level in the course of the next day (Hughes et al., 1999). Studies of this kind provided a foundation for currently widely used controlled application of music in the course of treatment and rehabilitation of children and adults suffering from somatic and mental diseases.

Why Mozart? The answer to this question was sought by many researchers. The results of these works were summarized in a review conducted by Maria Dymnikova. Having analysed a number of music therapy reports, the author concluded that positive effects tended to be linked to the following factors: (1) String instruments are to be applied or, wind instruments with high acoustic sound frequencies, (2) Music is to be well-ordered in temperament, in modality (minor and major), modulation which is not to be irritating for the ear, (3) Voices are to be linked to one another in a polyphonic way, or as a homophonic melody, accompanied by bass, (4) Melodic phrases are to be divided into either four- or eight-tact periods, (5) Rhythm (agogics) is to correspond to human physiological rhythms, such as heart rate, brain rhythms, breathing cycles, (this regularity is proper for the second (slow) part of a number of instrumental concerts of the Baroque art and of the early Classicism), (6) Volume is to be in the lower part of the volume register (with a range of up to $50 \mathrm{~dB}$ ), with volume changes occurring gradually and within the aforementioned volume range (Dymnikova, 2016). All of these properties apply to the music by Mozart and other "old classics" composed before 1790,and to a number of later compositions, like "Clair de Lune" (Moonlight) by Claude Debussy.

It seems obvious that all of the above-mentioned characteristics are significant only for those respondents for whom European classical music (from Bach and Mozart to Beethoven) forms part of the cultural heritage and, accordingly, is perceived as standard/normal. The degree of applicability of this principle to other musical traditions and the nature of necessary adjustments that it would need form a subject of a special 'identity-specific' study.

Since the effect in practically all cases turned out to be short-term (lasting for not more than several days), one could assume that listening to music every day would be a good idea. 
Having analysed the lifespan of a large number of professional musicians, Russian researchers Georgiy Zharinov and Vladimir Anisimov have recently come to an interesting conclusion: musicians performing classical music tend to live significantly longer than rock musicians (71 years for the former ones, and 45 years for the latter ones (men), and 81 and 38 for women, respectively). Another conclusion of their study consisted in the fact that famous and highly respected classical musicians tended live for at least ten years longer than ordinary ones. Thus the long-livers form a much larger part among prominent classical musicians than among the general population. This means that long and constant exposure to classical music could be really good for one's health (Zharinov, Anisimov, 2014). At the same time, life expectancy of rock musicians, as well as of folk singers performing songs written and composed by them, is significantly lower than average.

When studying the Mozart effect, psychological testing, brain activity registration (especially in the EEG band pass), and hormonal status measurements were widely used, but no study of telomere lengths and telomerase activity was conducted. Telomeres are the terminal regions of chromosomes, the length of which is nowadays considered to be a marker of biological aging. Numerous studies have shown associations between the telomere length and somatic or psychiatric disorders. Thus our pilot study was planned as an attempt to fill in this gap.

\section{MATERIALS AND METHODS}

\section{Description of groups and general outline of the experiment}

The study involved 63 practically healthy young (aged $24 \pm 5$ years), randomly selected Russianspeaking students, who were urban dwellers (residents of St. Petersburg, Russia). The volunteers underwent medical examination, filled in the informed consent form and a set of psychological questionnaires. Three $\mathrm{ml}$ of peripheral blood were collected in each case. After that, our subjects were divided into three subgroups $(20,21$, and 22 people in each). Each group lis- tened to music of a specific type for 14 days, 90 minutes each day. At the end of the two-week course, blood samples were collected again and similar psychological questionnaires were administered for the second time. We provided detailed descriptions of the questionnaires and published them earlier (Spivak et al., 2016a). Within the framework of this experiment, brain correlates of music perception, both in EEG and ultra-slow band passes, were studied (Spivak et al., 2016b).

There were no professional musicians among the subjects of our research. The majority had not graduated from even a musical college, which is quite a common form of secondary education in Russia. There were 16 subjects of this kind in subgroup 1, 15 in subgroup 2, and 16 in subgroup 3. Those who had graduated from a musical college were three in subgroup 1, three in subgroup 2, and four in subgroup 3. At the same time, the majority of our respondents reported that they were feeling quite positive to music. Many of them listened to some kind of musical recordings in the course of their everyday life: there were 12 such respondents in subgroup 1, five in subgroup 2, and 19 in subgroup 3 . Thus our respondents seemed to be quite representative of the population in general. This aspect seems to be fairly important for our study as the brain of a professional musician tends to function in the course of listening to music in a way different from that of ordinary people (Gaser, Schlaug, 2003; Bernardi et al., 2006).

Subgroup 2 listened to light classical music. The recordings we used were officially recommended by the Centre of Rehabilitation Medicine of the Ministry of Health of the Russian Federation as means for "stress reduction, relaxation, and healing". Musical fragments of this kind fully met the criteria proposed by Maria Dymnikova (Dymnikova, 2016).

Subgroup 3 listened to music which was sharply different, in both the key and timbre, from that of subgroup 2. The recordings applied in this case were synthesized by iAwake Technologies, USA, based on the concept of the psychologist Eric Thompson, a prominent expert in this field (for more detailed information, see: 
http://www.iawaketechnologies.com/ru/iawakescience). Referring to different traditions and techniques, recordings provided by iAwake Technologies attempted to activate healing mechanisms of the human body and psyche; they could be either relaxing or activating or both. Thus subgroup 2 listened to music from the realm of their cultural heritage, in the most general sense of this term. As for subgroup 3, the situation was opposite (cf. McCraty et al., 1998).

Subgroup 1 served as the control group. Thus, its members had to listen to sounds that would preferably not be music (singing, recitative) and would be neutral to the dichotomy "cultural tradition - cultural innovation". At the same time, they had to sound fairly common for every member of the subgroup 1 . We chose sounds of living nature as they complied to all of these requirements. The corresponding recordings were recommended by the aforementioned centre of the Federal Ministry of Health. Our choice was quite novel for studies of this kind.

Investigation of genetic polymorphism. To determine allelic polymorphism at the 5-HTTLPR locus of the 5-HTT gene, which was performed following the common protocol (Smirnova et al., 2012a), PCR reaction was performed, according to the previously described methodology (Woods et al., 2005; Heyer et al., 2004). Genotyping C102T variants of the 5_HTR2A gene was performed, following the common protocol (Smirnova et al., 2012b), by two-primer PCR, with subsequent treatment of the obtained product by MspI restriction endonuclease (Inayama et al., 1996). DNA fragments were separated by electrophoresis in polyacrylamide gel.

Measurement of the telomere length in the lymphocyte fraction of peripheral blood was carried out by a quantitative real-time PCR method according to the original protocol taken from literature (Eastwood et al., 2017). The mean length of telomeres in the sample (in $\mathrm{kbp}$ ) was calculated according to the procedure (Lapham et al., 2015), using dilutions of a calibrator-84-member synthetic oligonucleotide consisting of telomeric repeats TTAGGG. Since a large amount of information has by now been accumulated on significant spread of data concerning the telomere length by the RT-PCR method (Cawthon, 2002; O'Callaghan et al., 2008), and since individual differences tend to be rather large (Smirnova et al., 2012c), we registered the mean values of two measurements of telomere lengths, one of them prior to music course, and the second one after it. Changes greater than \pm 30 base pairs (bp) were taken into account. Thus all our subjects were divided into those whose telomere length rose by more than $30 \mathrm{bp}$, those whose telomere length stayed within the limits of $\pm 30 \mathrm{bp}$, and those whose telomere length shortened by more than $30 \mathrm{bp}$.

Telomerase activity was measured using TRAPEZE RT Telomerase detection Kit (Merc, Germany) according to the protocol recommended by the producer. Protein concentrations in cell extracts were determined by using the bicinchoninic acid assay (Pierce BCA kit). One $\mathrm{mkg}$ of protein was taken per reaction. Since the activity of telomerase is rather labile, we took into account only the increase or decrease in its activity, compared to the situation before the music course, by $10 \%$ or more. As in the case of telomere lengths, our subjects were divided into three groups, i.e. those whose telomerase activity increased by more than $10 \%$, those whose telomerase activity stayed within $\pm 10 \%$, and those whose decrease in activity was bigger than $10 \%$.

\section{Statistical processing}

Statistical processing of the data was conducted by means of standard Statistica 6.0 package.

\section{RESULTS}

As a result of undertaking a two-week course of music therapy, telomere shortening prevailed in members of control subgroup 1, while they tended to become longer in members of "classical" subgroup 2 . The number of subjects whose telomere length became longer, did not change, and became shorter may be expressed by the ratio 4:5:11 in the case of control subgroup 1 , and by ratio 13:3:5 in the case of 'classical' subgroup 2. The corresponding data are presented in Table 1. 
Table 1. Alteration of the telomere length and telomerase activity as a result of music therapy

\begin{tabular}{c|c|c|c|c|c|c}
\hline Subgroup Index No. & \multicolumn{2}{|c|}{$\mathbf{1}$ (control) } & \multicolumn{2}{c|}{$\mathbf{2}$ (classical) } & \multicolumn{2}{c}{3 (non-classical) } \\
\hline & $\begin{array}{c}\text { Telomere } \\
\text { length } \\
\text { alteration }\end{array}$ & $\begin{array}{c}\text { Telomer- } \\
\text { ase activity } \\
\text { alteration }\end{array}$ & $\begin{array}{c}\text { Telomere } \\
\text { length } \\
\text { alteration }\end{array}$ & $\begin{array}{c}\text { Telomerase } \\
\text { activity } \\
\text { alteration }\end{array}$ & $\begin{array}{c}\text { Telomere } \\
\text { length } \\
\text { alteration }\end{array}$ & $\begin{array}{c}\text { Telomerase } \\
\text { activity } \\
\text { alteration }\end{array}$ \\
\hline 1 & + & + & + & + & + & + \\
\hline 2 & + & 0 & + & + & + & + \\
\hline 3 & + & - & + & + & + & + \\
\hline 4 & + & - & + & + & + & + \\
\hline 5 & 0 & 0 & + & + & + & + \\
\hline 6 & 0 & 0 & + & 0 & + & 0 \\
\hline 7 & 0 & - & + & 0 & + & + \\
\hline 8 & 0 & - & + & 0 & + & + \\
\hline 9 & 0 & - & + & - & 0 & + \\
\hline 10 & - & 0 & + & - & 0 & - \\
\hline 11 & - & 0 & + & - & - & - \\
\hline 12 & - & 0 & + & - & - & + \\
\hline 13 & - & 0 & + & - & - & + \\
\hline 14 & - & - & 0 & 0 & - & + \\
\hline 16 & - & - & 0 & 0 & - & + \\
\hline 17 & - & - & 0 & - & - & + \\
\hline 19 & - & - & - & - & - & + \\
\hline 21 & - & - & - & - & - & + \\
\hline
\end{tabular}

'+' - a statistically significant increase in the telomere length or telomerase activity; 0 - absence of statistically significant alterations in these parameters; '-' - a statistically significant decrease in telomere length or telomerase activity (for details and discussion, see the main text of the present paper). Subjects' numbers (the first column from the left) designate different subjects in different groups. For the definition of statistical significance, cf. the main text of the present paper.

As shown by routine checks, no connection was found between these data, sex of our subjects,and the level of their musical education.

In control subgroup 1 , the increase in the telomere length (four cases) coincided with the increase in telomerase activity only in one case (which was in fact the only case of an increase in telomerase activity in subgroup 1); in one case there was no change in telomerase activity, and a decrease occurred in two cases. As to "classical" subgroup 2, an increase in telomerase activity was observed in five cases out of 13 cases where an increase in the telomere length occurred; telomerase activity did not change in three cases and decreased in five cases. Thus in a short pilot experiment, $24 \%$ of the respondents reacted to classical music in a highly positive way. This tendency does not seem to be accidental, as in "classical" subgroup 2 , all respondents who had an increase in telom- erase activity had at the same time an increase in the telomere length (for details, cf. Table 2).

"Non-classical" subgroup 3, which listened to contemporary designer music, followed a sharply different pattern. (Designer music is a general term applied in present-day scientific biomedical sciences to define any kind of musical tracks " designed to have specific effects on the listener" (McCraty, Barrios-Choplin, Atkinson, Tomasino, 1998). In our experiment, this effect consisted in general relaxation and promotion of well-being).

An increase in telomerase activity was registered in 17 out of 22 subjects of this subgroup. This regularity seems to be quite essential as the activity of telomerase tends to decrease - or, not to change significantly - in other two subgroups (to speak in more detail, telomerase activity increased in only one case in control subgroup 1, and only in five cases in "classical" subgroup 2). 
Returning to subgroup 3, we may also state that despite the fact that telomerase activity increased in 17 out of 22 cases, the telomere length increased here only in eight cases out of 22 (for details, see Table 1). We wish to emphasize here that an increase in telomerase activity corresponded to the increase in telomere length only in five cases out of 17 . In other cases (i.e., in 12 cases out of 17), the opposite process took place (i.e., in two cases, the telomere length did not alter, and in ten cases it decreased). These data are statistically significant Comparative data are presented in the Figure.

Results of post-hoc analysis show that there was a statistically significant difference between control and classical music groups in the change of the telomere length. The dynamics of telomerase activity tended to differ significantly in two cases: when control subgroup 1 was compared with the non-classical subgroup 3 and when classical subgroup 2

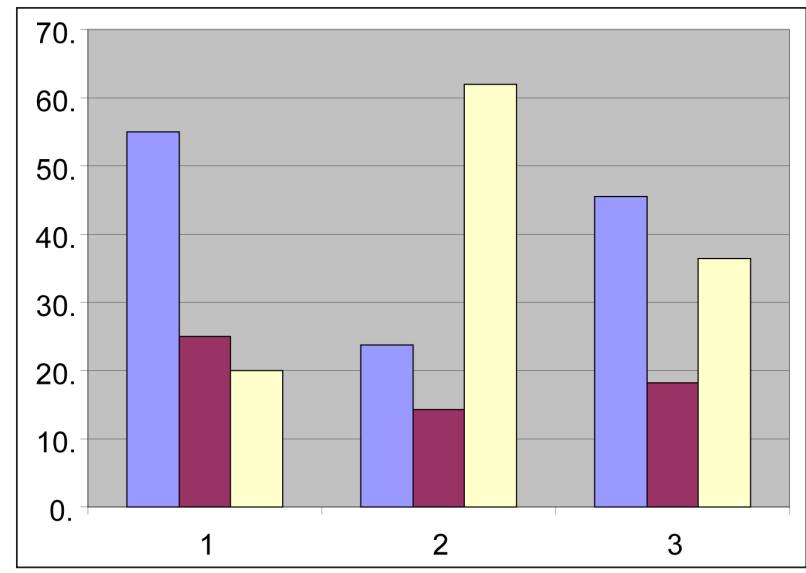

was compared with non-classical subgroup 3. In the case of classical subgroup 2, there was a significant positive correlation between the change in the telomere length and telomerase activity (the telomere length tended to increase with an increase in telomerase activity, and vice versa), while in the case of nonclassical subgroup 3 , the significant correlation was negative (the telomere length tended to decrease, while telomerase activity increased, and vice versa). Correlation coefficients are comparable by absolute values for both groups (for details, cf. Tables 2 and 3).

As clearly shown by subgroup 3, the telomere length tended to decrease there, while telomerase activity stepped up. One may suppose that listening to non-classical music would bring about definite stress that tended to reduce the telomere length. In order to avoid this, telomerase activity increased, which served as sort of a protective mechanism aimed at retain-

Figure. Changes in the telomere length as a result of music therapy

Abscissa axis: subgroups (1 - control, 2 - classical music, 3 - non-classical music). Ordinate axis: percentages. Columns: blue - a statistically significant decrease in the telomere length; red - no statistically significant changes; yellow - a statistically significant increase in the telomere length. For the definition of statistical significance, see the main text of the paper. The measurement error did not exceed 0.05 .

Table 2. Results of statistical comparison of alteration of the telomere length and telomerase activity as a result of music therapy

\begin{tabular}{|c|c|c|c|c|}
\hline \multirow[b]{2}{*}{ Index } & \multirow{2}{*}{$\begin{array}{l}p \text {-value in } \\
\text { Kruskal- } \\
\text { Wallis non- } \\
\text { parametric } \\
\text { test }\end{array}$} & \multicolumn{3}{|c|}{$\begin{array}{c}p \text {-value in post-hoc pairwise analysis by Dunn (correction of } p \text {-values by Sidak for } \\
\text { three pairwise comparisons) }\end{array}$} \\
\hline & & $\begin{array}{l}\text { Comparison: con- } \\
\text { trol - classical music (sub- } \\
\text { group } 1 \text { - subgroup } 2 \text { ) }\end{array}$ & $\begin{array}{c}\text { Comparison: con- } \\
\text { trol - non-classical music } \\
\text { (subgroup } 1 \text { - subgroup 3) }\end{array}$ & $\begin{array}{c}\text { Comparison: non-classical } \\
\text { music - classical music } \\
\text { (subgroup } 3 \text { - subgroup } 2 \text { ) }\end{array}$ \\
\hline $\begin{array}{c}\text { Change in the tel- } \\
\text { omere length }\end{array}$ & $0.03^{*}$ & $0.02^{*}$ & 0.45 & 0.13 \\
\hline $\begin{array}{l}\text { Change in the tel- } \\
\text { omerase activity }\end{array}$ & $0.0^{*}$ & 0.34 & $0.0^{*}$ & $0.0^{*}$ \\
\hline
\end{tabular}

Statistically significant differences (significance level 0.05 ) are marked by an asterisk $\left(^{*}\right)$. 
Table 3. Results of statistical comparison by Spearman's rank correlation coefficients of the change in the telomere length and telomerase activity as a result of music therapy

\begin{tabular}{ccc}
\hline Subgroup & Correlation coefficient & $p$-value \\
\hline 1 (control) & 0.15 & 0.26 \\
\hline 2 (classical) & $0.39^{\star}$ & 0.04 \\
\hline 3 (non-classical) & $-0.4^{*}$ & 0.03 \\
\hline
\end{tabular}

Statistically significant differences (significance level 0.05$)$ are marked by an asterisk $\left({ }^{*}\right)$.

ing the telomere length at the same level. This supposition is corroborated by structurally similar data acquired in studies of the relatives of patients suffering from Alzheimer's disease (Damjanovic et al., 2007), and of the carriers of the allele of predisposition to this disease (APOE $\varepsilon 4$, cf. Wikgren et al., 2012) and to depression (Wolkowitz et al., 2012).

Along with analysis of the telomere length and telomerase activity, we also studied two genes of the serotonin system. This aspect of our research forms the subject of a special paper. However, we wish to point out here that telomerase activity revealed strong correlation with the presence of the $\mathrm{L}$ allele of serotonin 5-HTT transporter gene (for corresponding data, cf. Tables 4 and 5).

We described the psychological and psychophysiological characteristics of the participants in this experiment earlier. The basic result consisted in stress reduction by subjects who passed a course of light classical music; the opposite occurred in the case of the modern designer music. As to the subtler mechanisms, stress coping strategies primitive in functional and ontogenetic terms (confrontation, avoidance) were demonstrated to be primarily activated, as well as such basic psychological defence mechanisms as suppression (Spivak et al., 2016a). Generalized common trends consisting primarily in activation of the frontal zones, accompanied by general slowdown of the occipital ones were demonstrated to occur in the EEG bandpass by subjects of subgroup 2. The opposite trend, comprising an absence of generalized common shifts in the EEG bandpass, was revealed in the case of subgroup 3. The general trend towards the reduction of the spectral power of signals in the ultraslow bandpass, especially in the frontal and temporal zones, was demonstrated, which tended to be sex-specific (Spivak et al., 2016b).

Table 4. Coefficients of ordinal logistic regression for model determining dependence of telomere length on subject subgroup, receptor gene genotype, transporter gene genotype, and age

\begin{tabular}{|c|c|c|c|c|c|c|c|}
\hline \multirow{2}{*}{\multicolumn{2}{|c|}{ Parameter }} & \multirow[b]{2}{*}{ Coefficient } & \multirow{2}{*}{$\begin{array}{l}\text { Standard } \\
\text { deviation }\end{array}$} & \multirow[b]{2}{*}{$t$-value } & \multirow[b]{2}{*}{$p$-value } & \multicolumn{2}{|c|}{ 95\% confidence interval } \\
\hline & & & & & & Lower & Upper \\
\hline \multirow{2}{*}{ Subgroup } & 2 (classical) & $1.68^{*}$ & 0.66 & 2.53 & 0.01 & 0.41 & 3.03 \\
\hline & 3 (non-classical & 0.68 & 0.62 & 1.10 & 0.27 & -0.52 & 1.94 \\
\hline \multirow{2}{*}{$\begin{array}{c}\text { Receptor gene } \\
\text { genotype }\end{array}$} & $\mathrm{A} 1 \mathrm{~A} 2$ & -1.58 & 1.28 & -1.23 & 0.22 & -4.74 & 0.73 \\
\hline & $\mathrm{A} 2 \mathrm{~A} 2$ & -1.06 & 1.32 & -0.80 & 0.42 & -4.27 & 1.35 \\
\hline \multirow{2}{*}{$\begin{array}{c}\text { Transporter } \\
\text { gene genotype }\end{array}$} & LS & 0.36 & 0.60 & 0.61 & 0.54 & -0.80 & 1.56 \\
\hline & SS & 0.29 & 0.83 & 0.35 & 0.73 & -1.35 & 1.96 \\
\hline \multicolumn{2}{|c|}{ Age } & 0.02 & 0.06 & 0.24 & 0.81 & -0.11 & 0.14 \\
\hline
\end{tabular}

Telomere length alteration was represented by proportional-odds cumulative logit model using group (control, classical music, non-classical music), receptor genotype (A1A1, A1A2, A2A2), transporter genotype (LL, LS, SS), and patient age as independent variables. Proportional odds assumption was validated by a likelihood ratio test. The model did not include the subject's sex as a variable, because it would have violated the proportional-odds assumption. Statistically significant differences (significance level 0.05 ) are marked by an asterisk $\left({ }^{*}\right.$ ). 
Table 5. Coefficients of ordinal logistic regression for model determining the dependence of telomerase activity on subject subgroup, receptor gene genotype, transporter gene genotype, and age

\begin{tabular}{|c|c|c|c|c|c|c|c|}
\hline \multirow{2}{*}{\multicolumn{2}{|c|}{ Parameter }} & \multirow{2}{*}{$\begin{array}{c}\text { Coeffi- } \\
\text { cient }\end{array}$} & \multirow{2}{*}{$\begin{array}{l}\text { Standard } \\
\text { deviation }\end{array}$} & \multirow{2}{*}{$t$-value } & \multirow{2}{*}{$p$-value } & \multicolumn{2}{|c|}{ 95\% confidence interval } \\
\hline & & & & & & Lower boundary & Upper boundary \\
\hline \multirow[b]{2}{*}{ Subgroup } & 2 (classical) & 0.93 & 0.67 & 1.39 & 0.16 & -0.36 & 2.29 \\
\hline & $\begin{array}{c}3 \text { (non-clas- } \\
\text { sical) }\end{array}$ & $3.54^{\star}$ & 0.81 & 4.35 & 0.00 & 2.05 & 5.27 \\
\hline \multirow{2}{*}{$\begin{array}{c}\text { Receptor gene } \\
\text { genotype }\end{array}$} & $\mathrm{A} 1 \mathrm{~A} 2$ & 0.20 & 1.01 & 0.19 & 0.85 & -1.75 & 2.38 \\
\hline & $\mathrm{A} 2 \mathrm{~A} 2$ & 1.35 & 1.10 & 1.23 & 0.22 & -0.74 & 3.69 \\
\hline \multirow{2}{*}{$\begin{array}{c}\text { Transporter } \\
\text { gene genotype }\end{array}$} & LS & $1.45^{\star}$ & 0.74 & 1.97 & 0.05 & 0.07 & 3.01 \\
\hline & SS & -0.03 & 0.92 & -0.04 & 0.97 & -1.88 & 1.79 \\
\hline \multicolumn{2}{|c|}{ Age } & 0.02 & 0.07 & 0.33 & 0.74 & -0.12 & 0.16 \\
\hline
\end{tabular}

Telomerase activity alteration was represented by proportional-odds cumulative logit model using group (control, classical music, non-classical music), receptor genotype (A1A1, A1A2, A2A2), transporter genotype (LL, LS, SS), and patient age, as independent variables. Proportional odds assumption was validated by likelihood ratio test. The model did not include the patient's sex as a variable, because it would have violated proportional-odds assumption. Statistically significant differences (significance level 0.05 ) are marked by an asterisk $\left(^{*}\right)$.

Correlation analysis of the entire set of brain data and data of molecular biological study forms the subject of a special paper.

\section{DISCUSSION}

Our basic hypothesis consisted in the fact that music therapy tends to reduce stress and promote adaptive performance; it probably leads to a decrease in the severity of senescence and to the extension of life expectancy. An increase in telomerase activity and in the telomere length tend to serve as an essential mechanism of this general trend. The order of notions in this enumeration matters, as the telomerase activity tends to be a rather unstable process that can easily change its direction under the influence of a number of factors, including the psychological ones, and in the course of a fairly short time. On the contrary, changes in the telomere length tend to be much more stable - in any case, taking much more time (for details, see Ornish et al., 2008).

Most of the studies into the changes in the telomere length and telomerase activity tend to regard time span of at least 2-3 months. For example, in men who were diagnosed with 'low-risk prostate cancer' and who agreed to participate in the programme of complex lifestyle changes (which included diet, active work, stress management, and social support), an increase in telomerase activity was registered after three months. As to the telomere length, significant changes were registered within five years after they had joined the program (see Ornish et al., 2013).

Telomerase activity increased by $17 \%$ as a result of 12-week psychotherapy in women with breast tumours (Lengacher et al., 2014). However, even six days of relaxation turned out to be sufficient to bring about a stable (lasting for up to ten months) "vacation effect": telomerase activity increased considerably in women who regularly practised meditation (Epel et al., 2016). These data are very similar to those obtained in the earlier studies of the "Mozart effect", namely, a brief but strongly pronounced reaction to one-time exposure accompanied by a possibility of its enhancement and prolongation in the case of continuation of music therapy. Based on this kind of data, we determined two weeks as the minimal time span for our experiment.

A large number of studies have been devoted to the analysis of the relationship between the telomere length and age. An overall decrease in the telomere length with age was shown, but this correlation was found only in the cases when the age was 75 years and above. In individuals over this age, by contrast, the age 
tended to positively correlate with the telomere length (Lapham et al., 2015).

In young people neither depressive nor anxiety disorders were directly related to the telomere length (Needham et al., 2015). At the same time, it was reliably shown that stress in childhood negatively affected the telomere length in the middle age. The result of a meta-analysis $(16,238$ patients in 27 independent studies) demonstrated significant telomere shortening in people who experienced stress at an early age (Hanssen et al., 2017). Maternal stress during pregnancy, but not her lifestyle, also lead to the shortening of the telomere length in newborns. The fact that the relationship between maternal prenatal stress and the telomere length was observed in offspring but not in mothers can be explained by high vulnerability to stress of a maturing organism during foetal development (Send et al., 2017).

Differences in the length of telomeres are especially pronounced in young and middle-aged people, since they are particularly vulnerable to socioeconomic stress factors (Schrock et al., 2017). At the same time, an analysis of more than 100,000 samples showed that dispersion of telomere lengths tends to increase with age (Lapham et al., 2015). A very large variation of telomere lengths was demonstrated both in our earlier works (Smirnova et al., 2012c) and in the present study. Based on this trend, we made a decision to apply the methodology of aggregating the telomere length, which was presented above.

The increase in telomerase activity is currently not treated as unambiguously as before. As it was regarded earlier, a decrease in telomerase activity in peripheral blood lymphocytes accompanies cellular aging and, consequently, the aging of the whole organism. This is also a case of action of psychological stress or of various diseases (for an earlier discussion, see our works Spivak et al., 2016; Bernadotte et al., 2016). Meditation has been proved to be able to alter this regularity (Lavretsky et al., 2013; Schutte, Malouff, 2014); the same is the case with lifestyle management (Daubenmier et al., 2012), psychological stress reduction (Epel et al., 2010), and decrease in low-density lipoproteins (Ornish et al., 2008). At the same time, a combination of short telomeres and high telomerase activity has been shown to be associated with various risk factors, including chronic psychological stress (Zalli et al., 2014). Based on these results, a new concept of stress response was recently formulated: it can either bring about a decrease in telomerase activity, leading to a shortening of telomeres, or an increase in telomerase activity, allowing it to maintain or even to increase the telomere length (Beery et al., 2012; for a constructive review, see Deng et al., 2016).

Thus adjustment of telomerase activity seems to be highly important for maintaining the overall health level. Complex interactions observed between the level of telomerase activity in lymphocytes and the development of various diseases, including tumours, are to be properly evaluated (Gazzaniga, Blackburn, 2014). Data on the increase in telomerase activity in lymphocytes of our subjects who listened to non-traditional music can probably be explained along these lines (in fact, this effect was observed in 17 out of 22 persons, which in $59 \%$ of cases was accompanied by telomere shortening).

Complex analysis of the majority of studies conducted from 2011 to 2013 showed that a reliable link existed between the short allele of the serotonin transporter gene (S) and the risk of depression, as well as an increased level of stress. However, in $26 \%$ of the studies such a connection was not found (Sharpley et al., 2014). Our results showing the correlation of the L (long) allele with increased telomerase activity, that is, activation of the stress reduction mechanism, are consistent with these data.

In studies into the Mozart effect, a reduction in the level of cortisol was demonstrated, for example as a result of music therapy in patients with cardiovascular pathology or, in need of hemodialysis (Hou et al., 2017). In response to complex behavioural problems, an increase of $20 \%$ or more in cortisol was observed in less than half of the respondents. But it is in these people that the telomere length tends to reduce faster, accelerating the aging process in this way (Steptoe et al., 2017). When listening to Mozart's 
40th symphony, blood pressure significantly decreased, which was not the case when listening to ABBA music; however, the level of cortisol in the blood decreased in both cases (Trappe, Voit, 2016). Since high levels of cortisol tend to reduce telomerase activity (Choi et al., 2008), we can assume that listening to Mozart's music can positively influence telomerase activity (as it was demonstrated above).

There are many results linking psychological and behavioural characteristics with the telomere length (Starkweather et al., 2014) and many of these factors coincide with those described in the studies into the Mozart effect. Thus, after 12 weeks of practising yoga, biochemical markers of aging (including cortisol) were reduced, telomerase activity increased, and telomere lengths slightly increased (Tolahunase et al., 2017). Higher optimism and a higher emotional level were associated with longer telomeres (after necessary adjustment with such factors as age and sex). A platform for a novel approach to the interplay of human biology and psychology was formed in this way (Schutte et al., 2016).

It was also demonstrated that music has a positive effect on cognitive ability (Pallesen et al., 2008). In a detailed study into the cognitive ability of older people, it was shown that the telomere length directly correlates with it (Hägg et al., 2017), suggesting that regular listening to music may be instrumental in maintaining the length of telomeres.

Music therapy is now increasingly used in the treatment of cancer patients, especially because having had a considerable level of life stress, they tended to become even more stressed in the course of chemical treatment (Carlson, 2016). Music therapy significantly reduced anxiety and helped to improve both the mood and subjective assessment of life quality of cancer patients preparing for radiotherapy treatment or undergoing it (Rossetti et al., 2017). It can also be a reasonable non-pharmacological method of coping with pain in the case of patients undergoing bone marrow transplantation: patients whose treatment included music therapy proved to need significantly lower doses of pain medication (Bates et al., 2017). These data are in agreement with recent results that showed a significant improvement in treatment, and increased survival, accompanied by reduction in cortisol and the telomere length, in patients with tumours, who actively participated in a long-term program of supportive psychotherapy adjusted for individual patterns (Carlson et al., 2015; 2017). Duration and regularity of sessions proved to be as important as in music therapy.

The Mozart effect in patients with epilepsy (Lin et al., 2014) can be compared with data on the telomere length in patients with other mental disorders, such as bipolar disorder (Powell et al., 2017), depression (Verhoeven et al., 2017), schizophrenia (Galletly et al., 2017; Schutte, Malouff, 2015), and increased anxiety (Malouff, Schutte, 2017). As shown by a number of authors, telomere shortening (compared to the corresponding mean level in the population) occurs in patients with the aforementioned diseases, while the telomere length corresponds to the severity of the given disease (Monroy-Jaramillo et al., 2017). Meditation and lifestyle changes can play an important role in maintaining telomere lengths.

People with cardiovascular diseases are also characterized by shortening of telomeres and an increased level of oxidative stress (Tian et al., 2017). These regularities seem to be less pronounced in those who practice an active lifestyle. In epilepsy, an increased level of oxidative stress is also found in cells (McElroy et al., 2017; Puttachary et al., 2015), so it can be assumed that the telomere length in such patients will be lower, like in patients with Down's syndrome, in whose cells oxidative stress is increased and telomeres are shortened (Gimeno et al., 2014).

At the same time, there are studies showing that telomeres are longer in patients with schizophrenia than in healthy volunteers; in our opinion, this might mean that in such patients protective mechanisms in the cells were activated to resist the oxidative stress (Nieratschker et al., 2013).

The assumption that meditation possibly influences the telomere length and telomerase 
activity was made by Epel et al. (Epel et al., 2009), while the first pilot study was published in 2009 (Jacobs et al., 2011). Existing in all traditional cultures, music serves as one of the oldest and universal tools for not only bringing an emotional pleasure, but also for altering one's psychological state, including the cognitive, behavioural, and communicative patterns (Kong, Karahalios, 2017). Music is definitely regarded now as an effective non-pharmacological agent in a number of conditions and diseases (Nwebube et al., 2017). As for the registration of such molecular markers of general health and longevity as the telomere length and telomerase activity in peripheral blood lymphocytes, it seems to be most constructive and timely.

\section{CONCLUSIONS}

Telomere length and telomerase activity tended to be affected considerably by a relatively short-term (two-week-long) of music therapy. The demonstrated effect was based on the application of standard procedures and methodologies of molecular biology.

In the case of classical music (i.e., music belonging to the subjects' cultural heritage), an increase in telomerase activity was often accompanied by an increase in the telomere length (that is, it occurred in the same subjects). Thus classical music tends to bring about less stress, to positively affect one's mood and physiology, and, finally, such essential aging markers as telomerase activity and the telomere length.

In the case of non-classical music, the increase in telomerase activity was normally not accompanied by an increase in the telomere length (that is, in most cases it occurred in different subjects). Interpreting this regularity, we suppose that perceiving non-classical music conditioned some stress, which tended to affect the telomere length in a negative way. In order to cope with this difficulty, telomerase was activated.

\section{ACKNOWLEDGEMENTS}

The authors are grateful to Evgeniy Pustoshkin, who, acting in contact with the American psy- chologist Eric Thompson, undertook the task of selecting non-traditional musical tracks, and to Andrey Mamonov, who conducted statistical processing of the data.

The present study was supported by the Russian Foundation for Basic Research, grant 1606-00172a.

Received 19 May 2018 Accepted 18 October 2018

\section{References}

1. Bates D, Bolwell B, Majhail NS, Rybicki L, Yurch M, Abounader D, Kohuth J, Jarancik S, Koniarczyk H, McLellan L, Dabney J, Lawrence C, Gallagher L, Kalaycio M, Sobecks R, Dean R, Hill B, Pohlman B, Hamilton BK, Gerds AT, Jagadeesh D, Liu HD. Music therapy for symptom management after autologous stem cell transplantation: results from a randomized study. Biol Blood Marrow Transplant. 2017; 23(9): 1567-72.

2. Beery AK, Lin J, Biddle JS, Francis DD, Blackburn EH, Epel ES. Chronic stress elevates telomerase activity in rats. Biol Lett. 2012; 8(6): 1063-6.

3. Bernadotte A, Mikhelson VM, Spivak IM. Markers of senescence. Telomere shortening as a marker of cellular senescence. Aging (Albany NY). 2016; 8(1): 3-11.

4. Bernardi L, Porta C, Sleight P. Cardiovascular, cerebrovascular, and respiratory changes induced by different types of music in musicians and non-musicians: the importance of silence. Heart. 2006; 92: 445-52.

5. Carlson LE, Beattie TL, Giese-Davis J, Faris P, Tamagawa R, Fick LJ, Degelman ES, Speca M. Mindfulness-based cancer recovery and supportive-expressive therapy maintain telomere length relative to controls in distressed breast cancer survivors. Cancer. 2015; 121(3): 476-84.

6. Carlson LE, Zelinski EL, Speca M, Balneaves LG, Jones JM, Santa Mina D, Wayne PM, Campbell TS, Giese-Davis J, Faris P, Zwicker J, 
Patel K, Beattie TL, Cole S, Toivonen K, Nation J, Peng P, Thong B, Wong R, Vohra S. Protocol for the MATCH study (Mindfulness and Tai Chi for cancer health): A preference-based multi-site randomized comparative effectiveness trial (CET) of Mindfulness-Based Cancer Recovery (MBCR) vs. Tai Chi/Qigong (TCQ) for cancer survivors. Contemp Clin Trials. 2017; 59: 64-76.

7. Carlson LE. Mindfulness-based interventions for coping with cancer. Ann N Y Acad Sci. 2016; 1373(1): 5-12.

8. Cawthon RM. Telomere measurement by quantitative PCR. Nucleic Acids Res. 2002; 30: e47.

9. Chabris CF. Prelude or requiem for the "Mozart effect"? Nature. 1999; 400: 826-7.

10. Choi J, Fauce SR, Effros RB. Reduced telomerase activity in human $\mathrm{T}$ lymphocytes exposed to cortisol. Brain Behav Immun. 2008; 22(4): $600-5$.

11. Damjanovic AK, Yang Y, Glaser R, KiecoltGlaser JK, Nguyen H, Laskowski B, Zou Y, Beversdorf DQ, Weng NP. Accelerated telomere erosion is associated with a declining immune function of caregivers of Alzheimer's disease patients. J Immunol. 2007; 179(6): 4249-54.

12. Daubenmier J, Lin J, Blackburn E, Hecht FM, Kristeller J, Maninger N, Kuwata M, Bacchetti P, Havel PJ, Epel E. Changes in stress, eating, and metabolic factors are related to changes in telomerase activity in a randomized mindfulness intervention pilot study. Psychoneuroendocrinology. 2012; 37(7): 917-28.

13. Deng W, Cheung ST, Tsao SW, Wang XM, Tiwari AF. Telomerase activity and its association with psychological stress, mental disorders, lifestyle factors and interventions: A systematic review. Psychoneuroendocrinology. 2016; 64: 150-63.

14. Dymnikova M. Physiological aspects of music and longevity. Advances in Gerontology. 2016; 6(2): 101-10.

15. Eastwood JR, Mulder E, Verhulst S, Peters A. Increasing the accuracy and precision of relative telomere length estimates by RT qPCR.
Mol Ecol Resour. 2017. doi: 10.1111/17550998.12711.

16. Epel E, Daubenmier J, Moskowitz JT, Folkman S, Blackburn E. Can meditation slow rate of cellular aging? Cognitive stress, mindfulness, and telomeres. Ann N Y Acad Sci. 2009; 1172: 34-53.

17. Epel ES, Lin J, Dhabhar FS, Wolkowitz OM, Puterman E, Karan L, Blackburn EH. Dynamics of telomerase activity in response to acute psychological stress. Brain Behav Immun. 2010; 24(4): 531-9.

18. Epel ES, Puterman E, Lin J, Blackburn EH, Lum PY, Beckmann ND, Zhu J, Lee E, Gilbert A, Rissman RA, Tanzi RE, Schadt EE. Meditation and vacation effects have an impact on disease-associated molecular phenotypes. Transl Psychiatry. 2016; 6(8): e880.

19. Galletly C, Dhillon VS, Liu D, Balzan RP, Hahn LA, Fenech MF. Shorter telomere length in people with schizophrenia: A preliminary study from Australia. Schizophr Res. 2017. pii: S0920-9964(17)30128-7.

20. Gaser C, Schlaug G. Brain structures differ between musicians and non-musicians. The Journal of Neuroscience. 2003; 23(27): 9240-5.

21. Gazzaniga FS, Blackburn EH. An antiapoptotic role for telomerase RNA in human immune cells independent of telomere integrity or telomerase enzymatic activity. Blood. 2014; 124(25): 3675-84.

22. Gimeno A, García-Giménez JL, Audí L, Toran N, Andaluz P, Dasí F, Viña J, Pallardó FV. Decreased cell proliferation and higher oxidative stress in fibroblasts from Down Syndrome fetuses. Preliminary study. Biochim Biophys Acta. 2014; 1842(1): 116-25.

23. Graziano AB, Peterson M, Shaw GL. Enhanced learning of proportional maths through music training and spatial-temporal reasoning. Neurol Res. 1999; 21: 139-52.

24. Hägg S, Zhan Y, Karlsson R, Gerritsen L, Ploner A, van der Lee SJ, Broer L, Deelen J, Marioni RE, Wong A, Lundquist A, Zhu G, Hansell NK, Sillanpää E, Fedko IO, Amin NA, Beekman M, de Craen AJM, Degerman S, 
Harris SE, Kan KJ, Martin-Ruiz CM, Montgomery GW; NeuroCHARGE Cognitive Working Group, Adolfsson AN, Reynolds CA, Samani NJ, Suchiman HED, Viljanen A, von Zglinicki T, Wright MJ, Hottenga JJ, Boomsma DI, Rantanen T, Kaprio JA, Nyholt DR, Martin NG, Nyberg L, Adolfsson R, Kuh D, Starr JM, Deary IJ, Slagboom PE, van Duijn CM, Codd V, Pedersen NL. Short telomere length is associated with impaired cognitive performance in European ancestry cohorts. Transl Psychiatry. 2017; 7(4): e1100.

25. Hanssen LM, Schutte NS, Malouff JM, Epel ES. The relationship between childhood psychosocial stressor level and telomere length: a metaanalysis. Health Psychol Res. 2017; 5(1): 6378.

26. Heyer NJ, Echeverria D, Bittner ACJr., Farin FM, Garabedian CC, Woods JS. Chronic low-level mercury exposure, BDNF polymorphism, and associations with self-reported symptoms and mood. Toxicol. Sci. 2004; 81: 354-63.

27. Hou YC, Lin YJ, Lu KC, Chiang HS, Chang CC, Yang LK. Music therapy-induced changes in salivary cortisol level are predictive of cardiovascular mortality in patients under maintenance hemodialysis. Ther Clin Risk Manag. 2017; 13: 263-72.

28. Hughes JR, Daaboul Y, Fino JJ, Shaw GL. The Mozart effect on epileptiform activity. Clin Electroencephalogr. 1998; 29: 109-19.

29. Hughes JR, Fino JJ, Melyn MA. Is there a chronic change of the "Mozart effect" on epileptiform activity? A case study. Clin Electroencephalogr. 1999; 30: 44-5.

30. Inayama $\mathrm{Y}$, Yoneda $\mathrm{H}$, Sakai T, et al. Positive association between a DNA sequence variant in the serotonin $2 \mathrm{~A}$ receptor gene with schizophrenia. Am J Med Genet. 1996; 67: 103-5.

31. Jacobs TL, Epel ES, Lin J, Blackburn EH, Wolkowitz OM, Bridwell DA, Zanesco AP, Aichele SR, Sahdra BK, MacLean KA, King BG, Shaver PR, Rosenberg EL, Ferrer E, Wallace BA, Saron CD. Intensive meditation training, immune cell telomerase activity, and psychological mediators. Psychoneuroendocrinology. 2011; 36(5): 664-81.
32. Kong HK, Karahalios K. Parental perceptions, experiences, and desires of music therapy. AMIA Annu Symp Proc. 2017; 2016: 1870-9. eCollection. 2016.

33. Lapham K, Kvale MN, Lin J, Connell S, Croen LA, Dispensa BP, Fang L, Hesselson S, Hoffmann TJ, Iribarren C, Jorgenson E, Kushi LH, Ludwig D, Matsuguchi T, McGuire WB, Miles S, Quesenberry CP Jr, Rowell S, Sadler M, Sakoda LC, Smethurst D, Somkin CP, Van Den Eeden SK, Walter L, Whitmer RA, Kwok PY, Risch N, Schaefer C, Blackburn EH. Automated assay of telomere length measurement and informatics for 100,000 subjects in the genetic epidemiology research on adult health and aging (GERA) cohort. Genetics. 2015; 200(4): 1061-72.

34. Lavretsky H, Epel ES, Siddarth P, Nazarian N, Cyr NS, Khalsa DS, Lin J, Blackburn E, Irwin MR. A pilot study of yogic meditation for family dementia caregivers with depressive symptoms: effects on mental health, cognition, and telomerase activity. Int J Geriatr Psychiatry. 2013; 28(1): 57-65.

35. Lengacher CA, Reich RR, Kip KE, Barta M, Ramesar S, Paterson CL, Moscoso MS, Carranza I, Budhrani PH, Kim SJ, Park HY, Jacobsen PB, Schell MJ, Jim HS, Post-White J, Farias JR, Park JY. Influence of mindfulness-based stress reduction (MBSR) on telomerase activity in women with breast cancer (BC). Biol Res Nurs. 2014; 16(4): 438-47.

36. Ligeois-Chauvel C, Peretz I, Babai M, Laguitton V, Chauvel P. Contribution of different cortical areas in the temporal lobes to music processing. Brain. 1998; 121: 1853-67.

37. Lin LC, Lee MW, Wei RC, Mok HK, Yang RC. Mozart K. 448 listening decreased seizure recurrence and epileptiform discharges in children with first unprovoked seizures: a randomized controlled study. BMC Complement Altern Med. 2014; 14: 17-9.

38. Malouff JM, Schutte NS. A meta-analysis of the relationship between anxiety and telomere length. Anxiety Stress Coping. 2017; 30(3): 264-72.

39. McCraty R, Barrios-Choplin B, Atkinson M, Tomasino D. The effects of different types of 
music on mood, tension, and mental clarity. Altern Ther Health Med. 1998; 4(1): 75-84.

40. McElroy PB, Liang LP, Day BJ, Patel M. Scavenging reactive oxygen species inhibits status epilepticus-induced neuroinflammation. Exp Neurol. 2017; 298(Pt A): 13-22.

41. Mellet E, Tzourio N, Crivello F, Joliot M, Denis M, Mazoyer B. Functional anatomy of spatial imagery generated from verbal instructions. J Neurosci. 1996; 16: 6504-12.

42. Monroy-Jaramillo N, Dyukova E, WalssBass C. Telomere length in psychiatric disorders: Is it more than an ageing marker? World J Biol Psychiatry. 2017; 25: 1-19.

43. Needham BL, Mezuk B, Bareis N, Lin J, Blackburn EH, Epel ES. Depression, anxiety and telomere length in young adults: evidence from the National Health and Nutrition Examination Survey. Mol Psychiatry. 2015; 20(4): 520-8.

44. Nieratschker V, Lahtinen J, Meier S, Strohmaier J, Frank J, Heinrich A, Breuer R, Witt SH, Nöthen MM, Rietschel M, Hovatta I. Longer telomere length in patients with schizophrenia. Schizophr Res. 2013. 149(1-3): 116-20.

45. Nwebube C, Glover V, Stewart L. Prenatal listening to songs composed for pregnancy and symptoms of anxiety and depression: a pilot study. BMC Complement Altern Med. 2017; 17(1): 256.

46. O'Callaghan NJ, Dhillon VS, Thomas P, Fenech M. A quantitative real-time PCR method for absolute telomere length. Biotechniques. 2008; 44: 807-9.

47. Ornish D, Lin J, Daubenmier J, Weidner G, Epel E, Kemp C, Magbanua MJ, Marlin R, Yglecias L, Carroll PR, Blackburn EH. Increased telomerase activity and comprehensive lifestyle changes: a pilot study. Lancet Oncol. 2008; 9(11): 1048-57.

48. Ornish D, Lin J, Chan JM, Epel E, Kemp C, Weidner G, Marlin R, Frenda SJ, Magbanua MJ, Daubenmier J, Estay I, Hills NK, Chainani-Wu N, Carroll PR, Blackburn EH. Effect of comprehensive lifestyle changes on telomerase activity and telomere length in men with biopsy-proven low-risk prostate cancer: 5-year follow-up of a descriptive pilot study. Lancet Oncol. 2013. 14(11): 1112-20.

49. Ornish D, Lin J, Daubenmier J, Weidner G, Epel E, Kemp C, Magbanua MJ, Marlin R, Yglecias L, Carroll PR, Blackburn EH. Increased telomerase activity and comprehensive lifestyle changes: a pilot study. Lancet Oncol. 2008; 9(11): 1048-57.

50. Pallesen KJ, Brattico E, Bailey CJ, Korvenoja A, Gjedde A. Cognitive and emotional modulation of brain default operation. J Cogn Neuroscience. 2008; 21: 1065-80.

51. Platel H, Price C, Baron JC, Wise R, Lambert J, Frackowiak RS, Lechevalier B, Eustache F. The structural components of music perception: a functional anatomical study. Brain. 1997; 120: 229-43.

52. Powell TR, Dima D, Frangou S, Breen G. Telomere Length and Bipolar Disorder. Neuropsychopharmacology. 2017. doi: 10.1038/ npp.2017.125

53. Puttachary S, Sharma S, Stark S, Thippeswamy T. Seizure-induced oxidative stress in temporal lobe epilepsy. Biomed Res Int. 2015: 745613. doi: 10.1155/2015/745613.

54. Rauscher FH, Robinson KD, Jens JJ. Improved maze learning through early music exposure in rats. Neurol Res. 1998; 20: 427-32.

55. Rauscher FH, Shaw GL, Ky KN. Music and spatial task performance. Nature. 1993; 365: 611.

56. Rauscher FH, Shaw GL, Levine LJ, Wright EL, Dennis WR, Newcomb RL. Music training causes longterm enhancement of preschool children's spatial-temporal reasoning. Neurol Res. 1997; 19: 2-8.

57. Rauscher FH. Comment. Nature. 1999; 400: 827.

58. Rideout BE, Dougherty S, Wernert L. Effect of music on spatial performance: a test of generality. Percept Motor Skills. 1998; 86: 512-4.

59. Rideout BE, Laubach CM. EEG correlates of enhanced spatial performance following exposure to music. Percept Motor Skills. 1996; 82: 427-32. 
60. Rossetti A, Chadha M, Torres BN, Lee JK, Hylton D, Loewy JV, Harrison LB. The Impact of Music Therapy on Anxiety in Cancer Patients Undergoing Simulation for Radiation Therapy. Int J Radiat Oncol Biol Phys. 2017; 99(1): 103-10.

61. Schrock JM, Adler NE, Epel ES, Nuru-Jeter AM, Lin J, Blackburn EH, Taylor RJ, Chae DH. Socioeconomic status, financial strain, and leukocyte telomere length in a sample of African American midlife men. J Racial Ethn Health Disparities. 2017. doi: 10.1007/s40615-0170388-3.

62. Schutte NS, Malouff JM. A meta-analytic review of the effects of mindfulness meditation on telomerase activity. Psychoneuroendocrinology. 2014; 42: 45-8. doi: 10.1016/j.psyneuen. 12.017.

63. Schutte NS, Malouff JM. The association between depression and leukocyte telomere length: a meta-analysis. Depress Anxiety. 2015; 32(4): 229-38.

64. Schutte NS, Palanisamy SK, McFarlane JR. The relationship between positive psychological characteristics and longer telomeres. Psychol Health. 2016; 31(12): 1466-80.

65. Send TS, Gilles M, Codd V, Wolf I, Bardtke S, Streit F, Strohmaier J, Frank J, Schendel D, Sütterlin MW, Denniff M, Laucht M, Samani NJ, Deuschle M, Rietschel M, Witt SH. Telomere length in newborns is related to maternal stress during pregnancy. Neuropsychopharmacology. 2017. doi: 10.1038/npp.2017.73

66. Sharpley CF, Palanisamy SK, Glyde NS, Dillingham PW, Agnew LL. An update on the interaction between the serotonin transporter promoter variant (5-HTTLPR), stress and depression, plus an exploration of non-confirming findings. Behav Brain Res. 2014; 273: 89-105. doi: 10.1016/j.bbr.2014.07.030.

67. Smirnova TYu, Spivak DL, Zakharchuk AG, Spivak IM. Distribution of polymorphism of gene serotonin transporter 5-HTTLPR in population of the North-West of Russia. Advances in Gerontology. 2012; 25; 1: 29-34. Russian.

68. Smirnova TYu, Runov AL, Vonsky MS, Spivak DL, Zakharchuk AG, Mikhelson VM,
Spivak IM. Telomere length in a population of long-lived people of the Northwestern region of Russia. Cell and Tissue Biology. 2012; 6, Nos. 5-6: 465-72.

69. Smirnova TYu, Spivak DL, Yakupova GS, Zakharchuk AG, Spivak IM. Distribution of structural polymorphisms of angiotensin converting enzyme and serotonin receptor (5_ HT2A) genes among long-living individuals from Northwestern Russia. Advances in Gerontology. 2012; 2(3): 247-52.

70. Spivak DL, Pustoshkin EA, Khesina AA, Zakharchuk AG, Spivak IM. Psychological effects of perception of traditional/non-traditional music and their brain correlates. Article 1: Psychological effects. International Journal of Cultural Research. 2016; 1(22): 142-55.

71. Spivak DL, Shemyakina NV, Nagornova ZV, Pustoshkin EA, Khesina AA, Zakharchuk AG, Spivak IM. Psychological effects of perception of traditional/non-traditional music and their brain correlates. Article 2: Brain correlates. International Journal of Cultural Research. 2016; 2(23): 159-69.

72. Spivak IM, Mikhelson VM, Spivak DL. Telomere length, telomerase activity, stress and aging. Advances in Gerontology. 2016; 6(1): 29-35.

73. Starkweather AR, Alhaeeri AA, Montpetit A, Brumelle J, Filler K, Montpetit M, Mohanraj L, Lyon DE, Jackson-Cook CK. An integrative review of factors associated with telomere length and implications for biobehavioral research. Nurs Res. 2014; 63(1): 36-50.

74. Steptoe A, Hamer M, Lin J, Blackburn EH, Erusalimsky JD. The Longitudinal Relationship Between Cortisol Responses to Mental Stress and Leukocyte Telomere Attrition. J Clin Endocrinol Metab. 2017; 102(3): 962-9. doi: 10.1210/ jc.2016-3035.

75. Tian R, Zhang LN, Zhang TT, Pang HY, Chen LF, Shen ZJ, Liu Z, Fang Q, Zhang SY. Association between oxidative stress and peripheral leukocyte telomere length in patients with premature coronary artery disease. Med Sci Monit. 2017; 23: 4382-90. 
76. Tolahunase M, Sagar R, Dada R. Impact of yoga and meditation on cellular aging in apparently healthy individuals: a prospective, open-label single-arm exploratory study. Oxid Med Cell Longev. 2017: 7928981.

77. Trappe HJ, Voit G. The cardiovascular effect of musical genres. Dtsch Arztebl Int. 2016; 113(20): 347-52.

78. Trappe HJ. The effects of music on the cardiovascular system and cardiovascular health. Heart. 2010; 96(23): 1868-71. doi: 10.1136/ hrt.2010.209858.

79. Verhoeven JE, Révész D, Picard M, Epel EE, Wolkowitz OM, Matthews KA, Penninx BW, Puterman E. Depression, telomeres and mitochondrial DNA: between- and within-person associations from a 10-year longitudinal study. Mol Psychiatry. 2017. doi: 10.1038/mp.2017.48.

80. Warren JD. Variations on the musical brain. J R Soc Med. 1999; 92: 571-5.

81. Wikgren M, Karlsson T, Nilbrink T, Nordfäll K, Hultdin J, Sleegers K, Van Broeckhoven C, Nyberg L, Roos G, Nilsson LG, Adolfsson R, Norrback KF. APOE $\varepsilon 4$ is associated with longer telomeres, and longer telomeres among $\varepsilon 4$ carriers predicts worse episodic memory. Neurobiol Aging. 2012; 33(2): 335-44.

82. Wolkowitz OM(1), Mellon SH, Epel ES, Lin J, Reus VI, Rosser R, Burke H, Compagnone M, Nelson JC, Dhabhar FS, Blackburn EH. Resting leukocyte telomerase activity is elevated in major depression and predicts treatment response. Mol Psychiatry. 2012; 17(2): 164-72.

83. Woods JS, Echeverria D, Heyer NJ, Martin MD, Rohlman DS, Farin FM, Li T. The association between genetic polymorphisms of coproporphyrinogen oxidase and an atypical porphyrinogenic response to mercury exposure in humans. Toxicol. Appl. Pharmacol. 2005; 206: 113-20.

84. Zalli A, Carvalho LA, Lin J, Hamer M, Erusalimsky JD, Blackburn EH, Steptoe A. Shorter telomeres with high telomerase activity are associated with raised allostatic load and impoverished psychosocial resources. Proc Natl Acad Sci USA. 2014. 111(12): 4519-24.
85. Zharinov GM, Anisimov VN. Musics and longevity. Advances in Gerontology. 2014; 4(4): 283-90.

Irina M. Spivak, Tatiana Yu. Smirnova, Arina

S. Urazova, Andrey L. Runov, Anastasia

A. Vasilishina, Andrey V. Kropotov, Dimitri

L. Spivak

\section{MUZIKOS TERAPIJOS POVEIKIS TELOME- RŲ ILGIUI: TRUMPA APŽVALGA IR EKSPE- RIMENTINIS TYRIMAS}

\section{Santrauka}

Šiame straipsnyje aptariamas ryšys tarp muzikos suvokimo ir telomeru ilgio. Telomerai yra laikomi bendros sveikatos ir gyvenimo trukmès žymeniu, nes jų ilgis priklauso nuo su amžiumi susijusių patologijų ar prisitaikymo prie aplinkos sąlygų. Straipsnyje aptariama galimybè išsaugoti telomerų ilgi, taip pat apžvelgiamos muzikos terapijos problemos ir perspektyvos. Tyrimo metu 63 sveiki rusakalbiai jaunuoliai (amžius $24 \pm 5$ metai), suskirstyti ị tris pogrupius, 14 dienų kasdieną 90 min. klausèsi konkrečios muzikos. Tiriamųjų kraujo mėginiai buvo surinkti prieš ir po muzikos klausymo ir apskaičiuotas telomerų ilgis bei telomerazės aktyvumas. Pastebetas ribotas, tačiau statistiškai patikimas telomeru pailgèjimas ir didesnis telomerazès aktyvumas muzikos klausymosi metu. Nustatyta, kad klasikinè muzika mažino stresą, teigiamai veike tiriamųjų nuotaiką ir fiziologiją - telomerazès aktyvumą ir telomerų ilgị. Neklasikinė muzika kèlè stresą, kuris neigiamai veikè telomerų ilgi, didino telomerazès aktyvumą.

Raktažodžiai: telomerų ilgis, telomerazès aktyvumas, muzikos terapija 